\title{
Emerging therapeutics
}

\author{
Gennaro Ciliberto*
}

We are pleased to announce the launch of a new section in the Journal of Translational Medicine entitled "Emerging Therapeutics". Scientific and technological advances are the necessary components in increasing our arsenal of weapons against complex diseases such as Cancer, Neurodegenerative and Cardiovascular diseases, Diabetes, Obesity as well as Infectious agents and, why not, also Aging. These days one of the most striking examples of emerging and highly successful technology is represented by the success of new genetic vaccines such as mRNA vaccines. With unprecedented short timelines, mRNA based vaccines have been able to demonstrate excellent safety and efficacy profiles in COVID-19 trials where they have received accelerated emergency approval, and are helping us overcome the SARS-CoV-2 pandemic crisis $[1,2]$. Hence, emerging therapeutics have received intense research efforts and high medical interest and it is for these reasons that a dedicated space has been provided by the Journal of Translational Medicine.

In the last few decades, we have witnessed the advent of several therapeutic breakthroughs based on the development of new technologies. Particularly worth mentioning is the generation, clinical development and approval of hundreds of monoclonal antibodies directed against a variety of targets both as surface molecules or as hormones and cytokines. Aside from the so called first generation "naked" antibodies, more recent developments have been moving in several new directions such as drug conjugated antibodies, bispecific antibodies, BiTes, nanobodies, Fc modified monoclonals, etc., consequently opening up a diversified array of therapeutic applications [3-5]. A deeper understanding of our immune system and of the mechanisms underlying target recognition

*Correspondence: gennaro54.ciliberto@gmail.com

IRCCS National Cancer Instituto Regina Elena, Rome, Italy by antibodies, combined with genetic engineering and cellular therapies, have been at the basis of the recent developments of CAR-Ts. CAR-Ts represent powerful weapons against cancers showing unmatched efficacy as well as duration of therapeutic responses. Although the currently approved CAR-Ts find their applications at the moment exclusively in hematological cancers, further challenges are represented by applications in the treatment of solid tumors where we expect to see major research investments made in the near future [6-8]. Yet another field of intense study is represented by gene therapy with viral vectors as well as, as mentioned above, by RNA and DNA therapeutics, where the development of nanotechnologies for the delivery of nucleic acids has been making huge progress in the few last years [9-12]. Also, in the near future we expect to see a growing number of clinical applications of CRISPR/CAS9 gene editing to the therapy of both inherited and acquired diseases, an approach which shows great promise as it was recognized by the Nobel Prize in chemistry 2020 award winners Emmanuelle Charpentier and Jennifer Doudna [13, 14]. Finally our increasing understanding of the importance of microbiota in disease pathogenesis and response to therapy is opening up novel therapeutic avenues. Hence we can expect an entire new wave of microbiotamodulating approaches based either on the delivery of selected bacterial strains or, alternatively, the identification of molecules capable to modify gut microbiota composition for the benefit of patients [15-17].

In addition to what is listed above, the next wave of "emerging therapeutics" will arise not only from the development of new technologies for drug development but also from the discovery of new intervention targets and the possibility for new drug combinations. In this regard, the extensive use of 'omics approaches, including next generation sequencing, single cell sequencing,

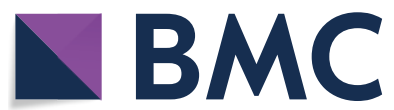

(c) The Author(s) 2021. This article is licensed under a Creative Commons Attribution 4.0 International License, which permits use, sharing, adaptation, distribution and reproduction in any medium or format, as long as you give appropriate credit to the original author(s) and the source, provide a link to the Creative Commons licence, and indicate if changes were made. The images or other third party material in this article are included in the article's Creative Commons licence, unless indicated otherwise in a credit line to the material. If material is not included in the article's Creative Commons licence and your intended use is not permitted by statutory regulation or exceeds the permitted use, you will need to obtain permission directly from the copyright holder. To view a copy of this licence, visit http://creativeco mmons.org/licenses/by/4.0/. The Creative Commons Public Domain Dedication waiver (http://creativecommons.org/publicdomain/ zero/1.0/) applies to the data made available in this article, unless otherwise stated in a credit line to the data. 
proteomics and metabolomics combined with data interpretation by high performance computing, molecular modeling and new algorithms of artificial intelligence is expanding day by day, a universe of targets to be tackled by conventional drug discovery or, alternatively, as discussed above, with the help of new technologies [18-20].

In this highly stimulating scenario, we will be delighted for our section to be considered for publication in the Journal of Translational medicine original papers, review and perspectives that report about advances in the field.

The Journal of Translational Medicine provides high standard peer-review process and represents a platform for efficiently communicating up-to-date results and scientific discussions. The new section on "Emerging Therapeutics" will guarantee high quality and competitive publications. The Editorial Board is looking forward to receiving your contributions.

\section{Authors' contributions}

GC conceived and wrote this editorial. The author read and approved the final manuscript.

\section{Declarations}

\section{Competing interests}

The author declares that he has no competing interests.

Received: 27 April 2021 Accepted: 27 April 2021

Published online: 05 May 2021

\section{References}

1. Sandbrink JB, Shattock RJ. RNA vaccines: a suitable platform for tackling emerging pandemics? Front Immnol. 2020;11:608460. https://doi.org/10. 3389/fimmu.2020.608460

2. Schoenmaker $L$, et al. mRNA-lipid nanoparticle COVID-19 vaccines: structure and stability. Int J Pharm. 2021;601:120586. https://doi.org/10.1016/j. ijpharm.2021.120586 (Online ahead of print).

3. Liu J, et al. Therapeutic advances in oncology. Int J Mol Sci. 2021;22(4):2008. https://doi.org/10.3390/ijms22042008.

4. Santos-Neto JF, et al. Technological advancements in monoclonal antibodies. Sci World J. 2021;2021:6663708. https://doi.org/10.1155/2021/ 6663708.eCollection2021.
5. Criscitello C, et al. Antibody-drug conjugates in solid tumors: a look into novel targets. J Hematol Oncol. 2021;14(1):20. https://doi.org/10.1186/ s13045-021-01035-z.

6. Edeline J, et al. CAR-T cells and BiTEs in solid tumors: challenges and perspectives. J Hematol Oncol. 2021;14(1):65. https://doi.org/10.1186/ s13045-021-01067-5.

7. Safarzadeh KP, et al. Strategies for dodging the obstacles in CART cell therapy. Front Oncol. 2021;11:627549. https://doi.org/10.3389/fonc.2021. 627549 (eCollection 2021)

8. Wagner J, et al. CART cell therapy for solid tumors: bright future or dark reality? Mol Ther. 2020;28(11):2320-39. https://doi.org/10.1016/j.ymthe. 2020.09.015.

9. Bulcha JT, et al. Viral vector platforms within the gene therapy landscape. Signal Transduct Target Ther. 2021;6(1):53. https://doi.org/10.1038/ s41392-021-00487-6.

10. Romano G, et al. microRNAs as novel therapeutics in cancer. Cancers. 2021;13(7):1526. https://doi.org/10.3390/cancers13071526.

11. Beck JD, et al. mRNA therapeutics in cancer immunotherapy. Mol Cancer. 2021;20(1):69. https://doi.org/10.1186/s12943-021-01348-0.

12. Hammond $\mathrm{SZ}$, et al. Delivery of oligonucleotide-based therapeutics: challenges and opportunities. EMBO Mol Med. 2021;13(4):e13243. https://doi. org/10.15252/emmm.202013243.

13. Saha $\mathrm{K}$, et al. The $\mathrm{NIH}$ somatic cell genome editing program. Nature. 2021;592(7853):195-204. https://doi.org/10.1038/s41586-021-03191-1.

14. Chuang Y-F, et al. Approach for in vivo delivery of CRISPR/Cas system: a recent update and future prospect. Cell Mol Life Sci. 2021;78(6):2683-708. https://doi.org/10.1007/s00018-020-03725-2.

15. Wilkinson JE, et al. A framework for microbiome science in public health. Nat Med. 2021. https://doi.org/10.1038/s41591-021-01258-0.

16. Mohamed A, et al. Drug-microbiota interaction in colon cancer therapy: impact of antibiotics. Biomedicines. 2021;9(3):259. https://doi.org/10. 3390/biomedicines9030259.

17. Sepich-Poore GD, et al. The microbiome and human cancer. Science. 2021;371 (6536):eabc4552. https://doi.org/10.1126/science.abc4552.

18. Zielinski JM, et al. High throughput multi-omics approaches for clinical trial evaluation and drug discovery. Front Immunol. 2021;12:590742. https://doi.org/10.3389/fimmu.2021.590742 (eCollection 2021).

19. Mohammadi E, et al. Applications of genome-wide screening and systems biology approaches in drug repositioning. Cancers. 2020;12(9):2694. https://doi.org/10.3390/cancers12092694.

20. Chaudari R, et al. An up-to-date overview of computational polypharmacology in modern drug discovery. Expert Opin Drug Discov. 2020;15(9):1025-44. https://doi.org/10.1080/17460441.2020.1767063.

\section{Publisher's Note}

Springer Nature remains neutral with regard to jurisdictional claims in published maps and institutional affiliations.

Ready to submit your research? Choose BMC and benefit from:

- fast, convenient online submission

- thorough peer review by experienced researchers in your field

- rapid publication on acceptance

- support for research data, including large and complex data types

- gold Open Access which fosters wider collaboration and increased citations

- maximum visibility for your research: over 100M website views per year

At BMC, research is always in progress.

Learn more biomedcentral.com/submissions 